\title{
Inhibition of Carrageenan-Induced Acute Inflammation in Mice by Oral Administration of Anthocyanin Mixture from Wild Mulberry and Cyanidin-3-Glucoside
}

\author{
Neuza Mariko Aymoto Hassimotto,, ${ }^{1,2}$ Vanessa Moreira, ${ }^{3}$ Neide Galvão do Nascimento, ${ }^{3}$ \\ Pollyana Cristina Maggio de Castro Souto, ${ }^{3}$ Catarina Teixeira, ${ }^{3}$ and Franco Maria Lajolo ${ }^{1,2}$ \\ ${ }^{1}$ Laboratório de Química e Bioquímica e Biologia Molecular de Alimentos, Departamento de Alimentos e Nutrição Experimental, \\ FCF, Universidade de São Paulo, Avenida Professor Lineu Prestes 580, Bloco 14, 05508-000 São Paulo, SP, Brazil \\ ${ }^{2}$ Núcleo de Apoio à Pesquisa em Alimentos e Nutrição (NAPAN), Universidade de São Paulo, 05508-000 São Paulo, SP, Brazil \\ ${ }^{3}$ Laboratório de Farmacologia, Unidade de Inflamação, Instituto Butantan, Avenida Vital Brasil 1500, \\ 05503-000 São Paulo, SP, Brazil
}

Correspondence should be addressed to Franco Maria Lajolo; fmlajolo@usp.br

Received 6 September 2012; Accepted 9 December 2012

Academic Editor: José Carlos Tavares Carvalho

Copyright (C) 2013 Neuza Mariko Aymoto Hassimotto et al. This is an open access article distributed under the Creative Commons Attribution License, which permits unrestricted use, distribution, and reproduction in any medium, provided the original work is properly cited.

\begin{abstract}
Anthocyanins are flavonoids which demonstrated biological activities in in vivo and in vitro models. Here in the anti-inflammatory properties of an anthocyanin-enriched fraction (AF) extracted from wild mulberry and the cyanidin-3-glucoside (C3G), the most abundant anthocyanin in diet, were studied in two acute inflammation experimental models, in the peritonitis and in the paw oedema assays, both of which were induced by carrageenan (cg) in mice. In each trial, AF and C3G (4 mg/100 g/animal) were orally administered in two distinct protocols: $30 \mathrm{~min}$ before and $1 \mathrm{~h}$ after cg stimulus. The administration of both AF and C3G suppresses the paw oedema in both administration times $(P<0.05)$. In the peritonitis, $\mathrm{AF}$ and $\mathrm{C} 3 \mathrm{G}$ reduced the polymorphonuclear leukocytes $(\mathrm{PMN})$ influx in the peritoneal exudates when administered $1 \mathrm{~h}$ after cg injection. AF was more efficient reducing the PMN when administered 30 min before cg. Both AF and C3G were found to suppress mRNA as well as protein levels of COX-2 upregulated by $\mathrm{cg}$ in both protocols, but the inhibitory effect on $\mathrm{PGE}_{2}$ production in the peritoneal exudates was observed when administered 30 min before $\mathrm{cg}(P<0.05)$. Our findings suggest that AF and C3G minimize acute inflammation and they present positive contributions as dietary supplements.
\end{abstract}

\section{Introduction}

Anthocyanins, glycosylated polyphydroxy, and polymethoxy derivates of flavilium salt are natural colorants belonging to the flavonoid family and largely intaken from vegetable foods [1]. These pigments are responsible for the pink, red, violet, and blue colours in the flowers, fruits, and vegetables. There is a great variety of anthocyanins spread in the nature but only six are the most common: cyanidin, pelargonidin, malvidin, peonidin, petunidin, and delfinidin [2]. Interest in biological effects of anthocyanins has increased during the last decade because of increasing evidence demonstrating their potential therapeutic effects. Some anthocyanins have demonstrated to inhibit the growth of cancerous cells [3-5], to decrease hyperglycemic levels [6] and to promote antiobesity effects $[7,8]$. Furthermore, anthocyanins possess antioxidant [9, 10] and anti-inflammatory [11-13] properties. This group of compounds has been demonstrated to modulate inflammation process dependent on the COX-2 pathway in vitro experimental protocols [14-18] and through the inhibition of nitric oxide biosynthesis [10]. 
Wild black mulberry (Morus nigra L.) extracts contains high level of anthocyanins. The identified anthocyanins are mainly cyanidin-3-glucoside (C3G), and in minor level cyanidin-3-rutinoside and pelargonidin derivate [19]. We previously reported that the anthocyanin-enriched extract (AF) obtained from wild black mulberry increased the plasma antioxidant capacity and the plasma catalase activity after oral intake in human [20]. Also, AF demonstrated inhibitory effect on the migration and invasion of a human lung cancer cell [5]. However, there are few studies that use in vivo experimental protocols, in order to demonstrate if oral intake of anthocyanins could affect inflammation. Since the anthocyanin is commonly intake daily from vegetable foods, it is important to establish evidence for the effect of anthocyanin consumption on health.

Inflammatory responses are a series of well-coordinated events that depend on the increase in vascular permeability and sequential release of inflammatory mediators, leading to oedema and arrival of inflammatory leukocytes to the site of inflammation, where neutrophils and macrophages are known to recruit and play pivotal roles in acute and chronic inflammation, respectively [21]. Cyclooxygenases (COXs) are the key enzymes in the synthesis of lipid mediators called prostaglandins observed in inflammation events. COXs convert free arachidonic acid, following its release from membrane phospholipids by phospholipases $\mathrm{A}_{2}$, to prostaglandin $\mathrm{H}_{2}$, the common precursor for all prostanoids. Nowadays, there are three COX isoforms named COX-1, COX-2, and COX-3 [22, 23]. COX-1 is a housekeeping enzyme, constitutively expressed in most mammalian tissues, and it is responsible for maintaining normal cellular physiologic functions. COX-2 is also present at a basal level in certain tissues, but its expression is induced in inflammatory cells and tissues in response to cellular activation by endotoxin, cytokines, mitogens, and other stimulus $[24,25]$. COX-2 is the main enzyme providing a mechanism for the generation of proinflammatory prostanoids, such as prostaglandin $\mathrm{E}_{2}$ $\left(\mathrm{PGE}_{2}\right)$, a potent vasodilator, which enhances oedema formation $[26,27]$. COX-3, in turn, has been cloned $[28,29]$, but its function have yet to be well studied.

Therefore, in this study, we have examined, in mice, the anti-inflammatory activity of oral administration of an anthocyanin-enriched extract obtained from mulberry and its major component, the $\mathrm{C} 3 \mathrm{G}$, in the acute inflammation, peritonitis and paw oedema assays, induced by carrageenan, mainly on COX-2 mRNA and protein expression and $\mathrm{PGE}_{2}$ production.

\section{Material and Methods}

2.1. Mulberry Anthocyanin Preparations. The anthocyaninenriched fraction (AF) was prepared from wild black mulberry according to the previously published method [19]. Briefly, the sample (approximately $5 \mathrm{~g}$ ) was extracted three times with $100 \mathrm{~mL}$ of methanol:water:acetic acid $(70: 30: 5, \mathrm{v}: \mathrm{v}: \mathrm{v})$ (Brinkmann homogeniser, PolytronKinematica GmbH, Kriens-Luzern, Sweden) in an ice bath. The homogenate was filtered under reduced pressure through filter paper (Whatman number 06). The methanol extract obtained was concentrated, under vacuum until methanol content elimination, using a rotary evaporator (Rotavapor RE 120, Buchi, Flawil, Sweden) and made up to $50 \mathrm{~mL}$ with distilled water. The extract $(25 \mathrm{~mL})$ was passed through polyamide (CC-6, Macherey-Nagel, Germany) column $(10 \mathrm{~g} / 60 \mathrm{~mL})$ previously conditioned with $50 \mathrm{~mL}$ of methanol and $100 \mathrm{~mL}$ of distilled water. Impurities were washed out with distilled water and retained flavonoids were eluted with $120 \mathrm{~mL}$ of methanol acidified with $0.1 \% \mathrm{HCl}$. The flow rate through the columns was controlled by means of a vacuum manifold Visiprep 24DL (Supelco, Bellefonte, PA). The eluate was evaporated to dryness under reduced pressure at $40^{\circ} \mathrm{C}$ and dissolved in distilled water prior administration. This fraction corresponds to AF. C3G was further purified from AF according to Chen et al. [5] by passing it through a Bio-Gel P-2 column $(40 \mathrm{~cm} \times 2.5 \mathrm{~cm})$ (Bio-Rad Laboratories, Hercules, CG), eluting it with aqueous acetic acid, $\mathrm{pH} 2.5$, and monitoring it by spectrophotometer at $520 \mathrm{~nm}$ (Hitachi L-4000 UV-vis detector). The fraction corresponding to C3G, which was confirmed by HPLC-DAD, was collected and lyophilized. C3G was dissolved in distilled water prior to administration.

2.2. Anthocyanin Quantification. For anthocyanin quantification, aliquots of AF and C3G were diluted with methanol: acetic acid (99:5, v:v) and filtered through a $0.45 \mu \mathrm{m}$ PTFE filter (Milipore Ltd., Bedford MA) prior to quantification by HPLC-DAD [19]. The column used was a Prodigy $5 \mu \mathrm{m}$ ODS3 (250 $\mathrm{mm} \times 4.6 \mathrm{~mm}$ i.d., Phenomenex Ltd.) and elution solvents were (A) water:THF:TFA $(98: 2: 0.1, \mathrm{v}: \mathrm{v}: \mathrm{v})$ and (B) acetonitrile. Solvent gradient consisted of $8 \% \mathrm{~B}$ at the beginning, $10 \%$ at $5 \mathrm{~min}, 17 \%$ at $10 \mathrm{~min}, 25 \%$ at $15 \mathrm{~min}$, $50 \%$ at $25 \mathrm{~min}, 90 \%$ at $30 \mathrm{~min}, 50 \%$ at $32 \mathrm{~min}$, and $8 \%$ at $35 \mathrm{~min}$ (run time, $35 \mathrm{~min}$ ). Eluates were monitored at 270 and $525 \mathrm{~nm}$. Flow rate was $1 \mathrm{~mL} / \mathrm{min}$; column temperature was $30^{\circ} \mathrm{C}$. Peak identification was performed by comparison of retention times and diode array spectral characteristics with the standards and the library spectra. Cochromatography was used when necessary. C3G, C3R, and pelargonidin (Plg) (Extrasynthese, Genay, France) were used as standard. The total anthocyanin content of AF was expressed as $\mathrm{C} 3 \mathrm{G}$ equivalent. The anthocyanin composition of $\mathrm{AF}$ is $85 \% \mathrm{C} 3 \mathrm{G}$, $12 \% \mathrm{C} 3 \mathrm{R}$, and 3\% Plg derivate and they were previously identified by LC-MS [19]. The anthocyanin profile of AF and the purity of $\mathrm{C} 3 \mathrm{G}$ are shown in Figure 1.

2.3. Animals. Male Swiss mice, weighing 18-20 g (approximately four weeks old), were acclimated to housing for at least 1 week prior to investigation. The night before the experiment, food was withdrawn from the cages but water was given ad libitum. Animals were randomly assigned to each treatment group and all testing was performed between 8:00 and 9:00 a.m. All animals were handled and experiments were conducted in accordance to the Guidelines for Animal Experimentation of the University of São Paulo, Brazil, after approval by the Ethics Committee of the Pharmacy Faculty of the University of São Paulo (Protocol number 53, FCF-USP). 


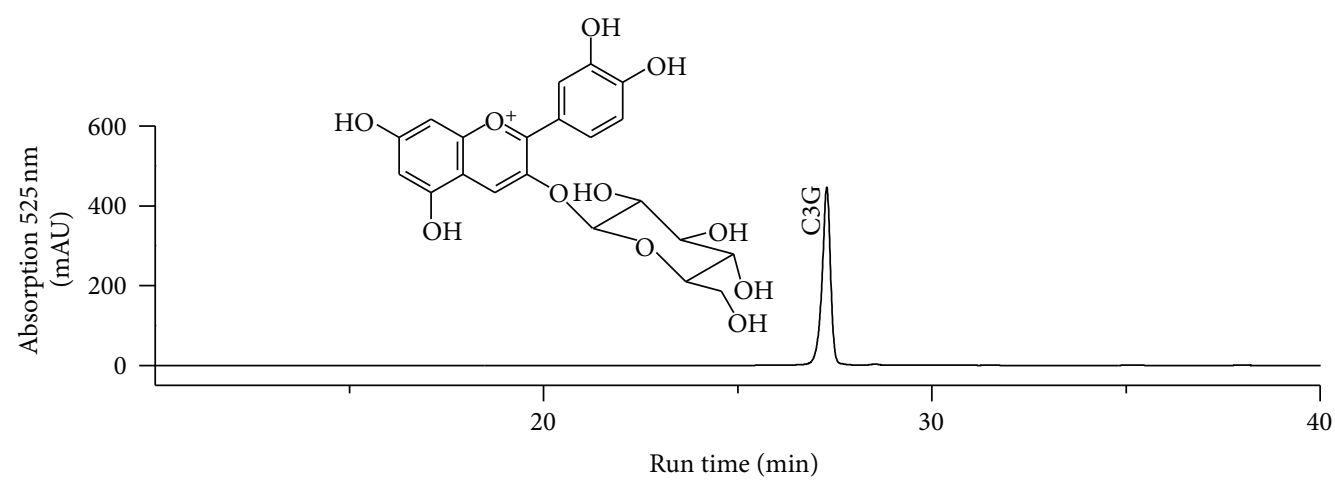

(a)

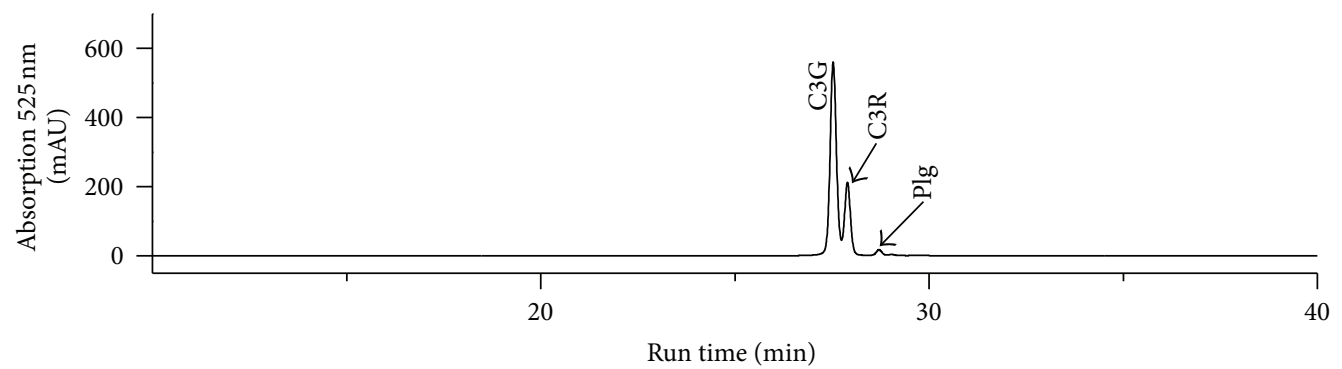

(b)

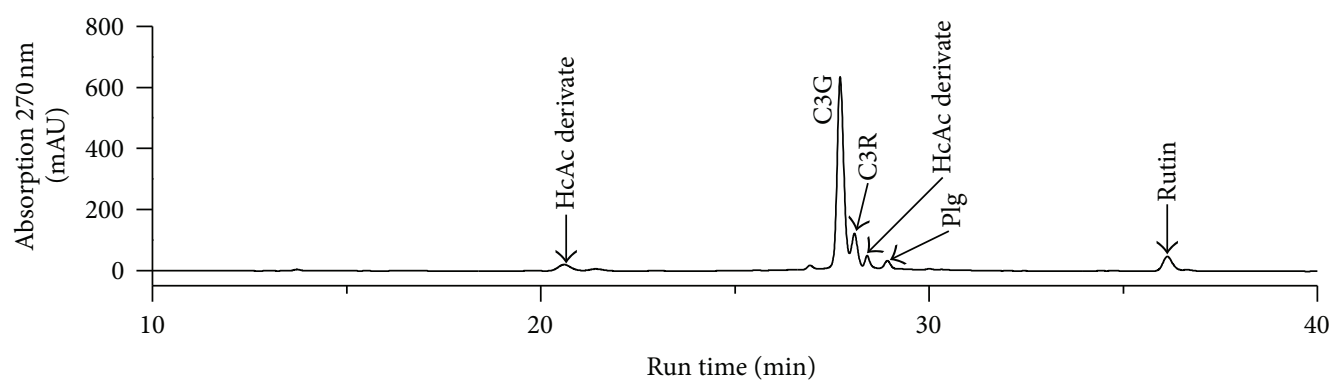

(c)

Figure 1: HPLC-DAD of cyanidin-3-glucoside (C3G) at $525 \mathrm{~nm}$ (a) and anthocyanin profile of AF at $525 \mathrm{~nm}$ (b) and $270 \mathrm{~nm}$ (c). Peaks were identified by MS/MS as C3G (structure showed), cyanidin-3-rutinoside (C3R), and rutin. Abbreviations: Hydroxycinnamic acid derivate (HcAc derivate) and pelargonidin (Plg).

2.4. Carrageenan-Induced Paw Oedema in Mice. To assess the effects of the AF and C3G on acute inflammation, the animals were deprived of food overnight and orally administered with an aqueous solution using an intragastric tube as described below.

AF Group: $200 \mu \mathrm{L}$ of the AF ( $4 \mathrm{mg}$ C3G equiv/100 g body weight) were administered $30 \mathrm{~min}$ before $(n=8)$ and $1 \mathrm{~h}$ after $(n=8)$ intraplantar (i.pl.) injection of $50 \mu \mathrm{L}$ cg in saline $(0.5 \%$ $\mathrm{m} / \mathrm{v}$ ) into the left hind paw.

C3G Group: $200 \mu \mathrm{L}$ of C3G ( $4 \mathrm{mg} / 100 \mathrm{~g}$ body weight) were administered 30 min before $(n=8)$ and $1 \mathrm{~h}$ after $(n=8)$ i.pl. injection of $50 \mu \mathrm{L}$ carrageenan $(\mathrm{cg})$ in saline $(0.5 \% \mathrm{~m} / \mathrm{v})$ into the left hind paw.

Control Group: $200 \mu \mathrm{L}$ of saline were administered $30 \mathrm{~min}$ before $(n=8)$ and $1 \mathrm{~h}$ after $(n=8)$ i.pl. injection of $50 \mu \mathrm{L} \mathrm{cg}$ in saline $(0.5 \% \mathrm{~m} / \mathrm{v})$ into the left hind paw.
Indomethacin Group: indomethacin $(1 \mathrm{mg} / \mathrm{kg}$, i.v) was administered $30 \mathrm{~min}$ before $(n=8)$ and $1 \mathrm{~h}$ after $(n=8)$ injection of $50 \mu \mathrm{L} \mathrm{cg}$ in saline $(0.5 \% \mathrm{~m} / \mathrm{v})$ into the left hind paw.

The contralateral paw was injected with $50 \mu \mathrm{L}$ of saline solution and used as a control. The volumes of both hind paws were measured by plethysmometry (model 7140 plethysmometer, Ugo Basile, Italy) 1, 2, 3, 4, and $5 \mathrm{~h}$ after the injection of $\mathrm{cg}$. The results were reported as the percent inhibition of the volume increase to be compared with the preinjection paw volume. Mean values of treated groups were compared with mean values of a control group and analyzed using statistical methods.

2.5. Carrageenan-Induced Peritonitis in Mice. The animals were deprived of food overnight and orally administered with one of the following solutions. 
AF Group: $200 \mu \mathrm{L}$ of the AF (4 mg C3G equiv/100 g body weight) were administered $30 \mathrm{~min}$ before $(n=8)$ and $1 \mathrm{~h}$ after $(n=8)$ intraperitoneal (i.p.) injection of $1 \mathrm{~mL}$ of $\mathrm{cg}$ in sterile saline $(0.3 \%, \mathrm{~m} / \mathrm{v})$.

C3G Group: $200 \mu \mathrm{L}$ of the C3G (4 mg/100 g body weight) were administered $30 \mathrm{~min}$ before $(n=8)$ and $1 \mathrm{~h}$ after $(n=8)$ i.p. injection of $1 \mathrm{~mL}$ of $\mathrm{cg}$ in sterile saline $(0.3 \%, \mathrm{~m} / \mathrm{v})$.

Carrageenan Control Group: $200 \mu \mathrm{L}$ of saline solution were administered 30 min before $(n=8)$ and $1 \mathrm{~h}$ after $(n=8)$ i.p. injection of $1 \mathrm{~mL}$ of $\mathrm{cg}$ in sterile saline $(0.3 \%, \mathrm{~m} / \mathrm{v})$.

Indomethacin Group: $200 \mu \mathrm{L}$ indomethacin $(4 \mathrm{mg} / 100 \mathrm{~g}$ body weight) were administered $30 \mathrm{~min}$ before $(n=8)$ and $1 \mathrm{~h}$ after $(n=8)$ i.p. injection of $1 \mathrm{~mL}$ of $\mathrm{cg}$ in sterile saline $(0.3 \%, \mathrm{~m} / \mathrm{v})$.

Saline Control Group: $200 \mu \mathrm{L}$ saline solution were administered $30 \mathrm{~min}$ before $(n=8)$ and $1 \mathrm{~h}$ after $(n=8)$ i.p. injection of $1 \mathrm{~mL}$ of sterile saline solution.

Three hours after cg injections, the animals were killed by overexposure to $\mathrm{CO}_{2}$ and the peritoneal exudate was withdrawn after washing the peritoneal cavity with $2 \mathrm{~mL}$ of saline solution. Aliquots of the washes were used to determine total cell counts. An aliquot of the $1 \times 10^{6}$ and $3 \times 10^{6}$ cells was centrifuged at $800 \mathrm{~g} / 6 \mathrm{~min} / 22^{\circ} \mathrm{C}$ and used for COX-2 expression analysis by western blotting and RT-PCR, respectively. The supernatant was used for $\mathrm{PGE}_{2}$ quantification.

2.6. Leukocyte Harvesting and Counting. Aliquots of the peritoneal washes were used to determine total cell counts in a Newbauer chamber after dilution $(1: 20, \mathrm{v}: \mathrm{v})$ in Turk's solution $(0.2 \%$ crystal violet dye in $30 \%$ acetic acid). For differential cell counts, cytospin preparations were stained with $\mathrm{Hema}^{3}$ stain. Differential cell counts were performed by counting at least 100 cells, which were classified as either polymorphonuclear or mononuclear cells, based on conventional morphological criteria.

2.7. Western Blotting. The precipitate of cells $\left(1 \times 10^{6}\right)$ was lisate with $100 \mu \mathrm{L}$ of sample buffer [30] and heated for $10 \mathrm{~min} / 100^{\circ} \mathrm{C}$. An aliquot of $14 \mu \mathrm{L}$ of the lisate was separated on SDS-polyacrylamide gels (10\%) at $150 \mathrm{~V}$ and electrophoretically transferred to nitrocellulose membrane (GE Healthcare, Buckinghamshire, UK). The membrane was blocked with $5 \%$ nonfat milk in Tris buffered saline with $0.05 \%$ Tween 20 and incubated $1 \mathrm{~h}$ at room temperature with the antibody against COX-2 (1:1500) (Cayman Chemicals, Ann Arbor, MI) followed by incubation in the same buffer with the appropriate anti-rabbit horseradish peroxidaseconjugated secondary antibody (GE Healthcare, Buckinghamshire, UK) for $1 \mathrm{~h}$ at room temperature $(1: 1500)$. Further, the membrane was also incubated with the antibody against $\beta$-actin $(1: 2000)$ (Sigma, St. Louis, USA) followed by incubation with the anti-mouse secondary horseradish peroxidase-conjugate $(1: 2000)$ (GE Healthcare, Buckinghamshire, UK). Immunoreactive bands were detected using ECL kit (GE Healthcare, Buckinghamshire, UK). Densities of the bands were determined by a GS 700 Densitometer (BioRad Laboratories, Richmond, CG) using the image analysis software from Molecular Analyst (Bio-Rad Laboratories, Richmond, CG).

2.8. RNA Preparation and Reverse Transcription-Polymerase Chain Reaction (RT-PCR). Cells $\left(3 \times 10^{6}\right)$ were washed once with sterile saline and mixed with $500 \mu \mathrm{L}$ of Trizol reagent (Invitrogen, Rockville, $\mathrm{MD}, \mathrm{EUA}$ ) and the RNA was extracted according to the manufacturer's instructions. Complementary DNA was synthesized using an ImpromII Reverse Transcription System (Promega, Madison, WI, USA) according to the manufacturer's instructions and conducted at a thermocycler Gene AMp (PCR System 2400, Applied Biosystems). PCR was performed by denaturing at $94^{\circ} \mathrm{C}$ for $60 \mathrm{~s}$, annealing at $57^{\circ} \mathrm{C}(\mathrm{COX}-2)$ and $60^{\circ} \mathrm{C}$ $\left(\beta\right.$-actin) for $1 \mathrm{~min}$ and by extension at $72^{\circ} \mathrm{C}$ for $60 \mathrm{~s}$. Thirty additional cycles for COX-2 and 25 cycles for $\beta$ actin were used for amplification. The primer pairs used for analysis were $5^{\prime}$-TTTGTTGAGTCGTTCGCCGGACGGA3 ' and 5'-CGGTATTGAGGAGAAGAGATGGGATT-3' for sense and antisense primers of the COX-2 gene, respectively [31]; 5' -TGGAATCCTGTGGCGTCCGTGAAAC-3' and 5' TAAAACGCGGCTCGGTAACGGTCCG-3' for sense and antisense primers of the $\beta$-actin gene, respectively [32], used as an inner control.

2.9. $P G E_{2}$ Quantification. Concentrations of $\mathrm{PGE}_{2}$ were determined by a specific enzyme immunoassay [33] using a commercial kit (Cayman Chemical Company, Ann Arbor, $\mathrm{MI})$. The extraction of $\mathrm{PGE}_{2}$ was performed on Sep Pak C18 columns (Waters Corporation, Milford, MA) and eluted with ethanol. In brief, $50 \mu \mathrm{L}$ aliquots of each extracted sample were incubated with the $\mathrm{PGE}_{2}$ conjugated with acetylcholinesterase and the specific rabbit antiserum in 96well plates, coated with anti-rabbit IgG mouse monoclonal antibody. After addition of the substrate, the absorbance of the samples was recorded at $405 \mathrm{~nm}$ in a microplate reader (Labsystem Multiscan), and concentrations of eicosanoids were estimated from standard curves.

2.10. Statistical Analysis. Results were presented as mean \pm EPM. The statistical analyses were performed by one way analysis of variance (ANOVA) and Tukey posthoc test for comparison, using the Statistic software package version 5.0 (StatSoft, Inc.). Results were considered statistically significant for $P$ values $<0.05$.

\section{Results and Discussion}

3.1. Effect of C3G and AF on Carrageenan-Induced Paw Oedema. The oral dose of both extracts and the two protocols applied in this study (30 min before or $1 \mathrm{~h}$ after inflammation stimulus) were chosen in order to provide high concentration of $\mathrm{C} 3 \mathrm{G}$ in the plasma based in its rapid absorption and excretion [20].

The inflammatory response to subplantar oedema induced by $\mathrm{cg}$ in mice was significantly reduced by prior and after oral administration of AF and C3G. Figures 2(a) 
and 2(b) show the time course of the paw oedema after i.pl. injection of $\mathrm{cg}(0.5 \% \mathrm{~m} / \mathrm{v})$. Carrageenan caused progressive increase in the paw oedema $1 \mathrm{~h}$ after the injection, presenting the maximum peak at $4 \mathrm{~h}$, decreasing to basal level after $5 \mathrm{~h}$. Before and after treatment of animals with indomethacin significantly reduced cg-induced paw oedema as expected, in comparison with the respective controls (saline). C3G ( $4 \mathrm{mg} / 100 \mathrm{~g}$ body weight), administered by gavage either $30 \mathrm{~min}$ before or $1 \mathrm{~h}$ after the cg stimulus significantly decreased $(P<0.05)$ the paw oedema (around $40 \%$ and up to $80 \%$, resp.) at the fourth hour after cg injection when compared with the control group (Figures 2(a) and 2(b)). Also, the oral administration of AF decreased the paw oedema approximately $40 \%$ in both administration times.

The dose of AF and C3G used in the present study is tentimes lower than that necessary of the anthocyanin mix from tart cherry to suppress the $25 \%$ complete Freund's adjuvant and cg-induced paw oedema [13] but closer than ginkgo biloba extract concentration necessary to inhibit the paw oedema induced by $\mathrm{cg}$ in rats [34]. This fact suggested that $\mathrm{C} 3 \mathrm{G}$ is one of the anthocyanins that presented high antiinflammatory activity.

It has been established that the paw oedema induced by the subplantar injection of $\mathrm{cg}$ is biphasic; the early phase involves the release of the mediators serotonin, histamine, and kinins, while the late phase is characterized by the infiltration of leukocytes and mediated only by prostaglandins [35]. These results suggest that the inhibitory effect of AF or $\mathrm{C} 3 \mathrm{G}$ on oedema formation is due to the inhibition of the synthesis and/or release of these mediators, in the early phase of inflammatory effect of cg, especially by inhibiting probably cyclooxygenase products. To support this observation, the data indicate that $\mathrm{C} 3 \mathrm{G}$ promoted similar effectiveness in suppressing oedema, when compared to the inhibitory profile of indomethacin, a COX activity inhibitor, on cg-induced inflammation.

\subsection{Effect of C3G and AF on Carrageenan-Induced Cellular} Influx into Peritoneal Cavity. Intraperitoneal administration of $\mathrm{cg}$ produces a sustained increase in postcapillary venule permeability, thereby leading to increased cellular infiltration, particularly of neutrophils [36]. The recruitment of leukocytes from the circulation to sites of inflammation is enhanced by a series of proinflammatory mediators, such as IL- 8 and vasoactive amines, ICAM and VCAM, that are produced and released into the tissue by mast cells, macrophages, and activated endothelial cells, as well as transmigrated leukocytes [36].

Figure 3 presents the total leukocyte influx and differential cell into the peritoneal cavities after oral administration of $\mathrm{C} 3 \mathrm{G}$ or $\mathrm{AF}$ ( $4 \mathrm{mg} / 100 \mathrm{~g}$ body weight) or indomethacin ( $4 \mathrm{mg} / 100 \mathrm{~g}$ body weight) or saline (control) $30 \mathrm{~min}$ before and $1 \mathrm{~h}$ after i.p. injection of $\mathrm{cg}(0.3 \% \mathrm{w} / \mathrm{v})$ or saline solution (without stimulus).

The oral administration of AF 30 min before the i.p. injection of cg caused a significant decrease $(P<0.05)$ in the number of total leukocytes (29\% decrease) (Figure $3(\mathrm{a})$ ), but not when administered $1 \mathrm{~h}$ after the stimulus.
No reduction of total leukocytes in peritoneal exudate was observed when indomethacin was injected $30 \mathrm{~min}$ before $\mathrm{cg}$. On the other hand, the $\mathrm{C} 3 \mathrm{G}$ decreases the number of total leukocytes when administered $1 \mathrm{~h}$ after the cg stimulus $(38 \%$ decrease) (Figure 3(d)). Similar effects were obtained with indomethacin administration, which promoted reduction of leukocytes (55\% decrease) when administered $1 \mathrm{~h}$ after i.p. injection of $\mathrm{cg}$.

Differential cell counts showed that leukocytes present in the peritoneal cavity, after i.p. injection of $\mathrm{cg}$, were predominantly polymorphonuclears (PMN), mainly neutrophils, when compared with the group that received saline (without stimulus). The mean values of PMN were $74 \pm$ $4 \times 10^{5}$ cells $/ \mathrm{mL}$, and $51 \pm 1 \times 10^{5}$ cells $/ \mathrm{mL}$, in the groups that received saline by gavage $30 \mathrm{~min}$ before and $1 \mathrm{~h}$ after $\mathrm{cg}$ injection, respectively (Figures 3(b) and 3(e)). On the other hand, in the group that received saline instead of cg (without stimulus), in both administration times, the mononuclear leukocytes $(\mathrm{MN})$ were predominant $\left(13 \pm 1 \times 10^{5}\right.$ cells $\left./ \mathrm{mL}\right)$. In addition, our results showed that cg injection caused a decrease in the number of $\mathrm{MN}$ in the peritoneal cavity $(7.1 \pm$ $0.1 \times 10^{5}$ cells $/ \mathrm{mL}$ ) (Figures $3(\mathrm{c})$ and $3(\mathrm{f})$ ).

Like what occurred with the total leukocytes, the number of PMN in peritoneal fluid in mice was significantly reduced when treated with C3G (39\% decrease) or indomethacin (40\% decrease) $1 \mathrm{~h}$ after the i.p cg stimulus, when compared to the control group that received saline orally (Figure 3(e)). On the other hand, AF administered $30 \mathrm{~min}$ before $\mathrm{cg}$, promoted a significant decrease in the recruited PMN (24\% decrease), compared to the control group (Figure 3(b)).

These results were different from those observed in other tissues, such as air pounch cg inflammation in mice and acute lung inflammation in rats where a decrease in the influx of cell was observed when $\mathrm{C} 3 \mathrm{G}$ was previously administered before the cg stimulus $[14,17]$.

In relation to $\mathrm{MN}$ influx, $\mathrm{C} 3 \mathrm{G}$ or $\mathrm{AF}$ or indomethacin administrated 30 min before cg injection did not change the decrease counts of $\mathrm{MN}$ promoted by cg injection (Figures 3(c) and 3(f)), when compared with the group without $\mathrm{cg}$ stimulus.

Since C3G was detected intact and in low concentration in plasma of rats after mulberry juice intake [20], the oral intake performed $1 \mathrm{~h}$ after cg stimulus probably could provide an ideal concentration of $\mathrm{C} 3 \mathrm{G}$ in plasma, resulting in the observed effect. However, this experimental protocol showed that $\mathrm{AF}$ is more effective than $\mathrm{C} 3 \mathrm{G}$ as a preventive compound against leukocyte migration, suggesting that the complex mixtures of anthocyanins in AF may provide antileukocyte influx effect mainly through a combination of additive and/or synergistic effects.

\subsection{Effect of C3G and AF on Carrageenan-Induced Cycloox-} ygenase-2 Expression in Peritonitis. The effect of $\mathrm{C} 3 \mathrm{G}$ or AF (4 mg/100 g body weight) on cg-induced COX-2 transcription was measured in peritoneal leukocytes by RT-PCR. As shown in Figures 4(a) and 4(c), the i.p. injection of $c g$ $(0.3 \% \mathrm{w} / \mathrm{v})$ drastically increased COX-2 mRNA and protein expression. On the other hand, the oral administration of 


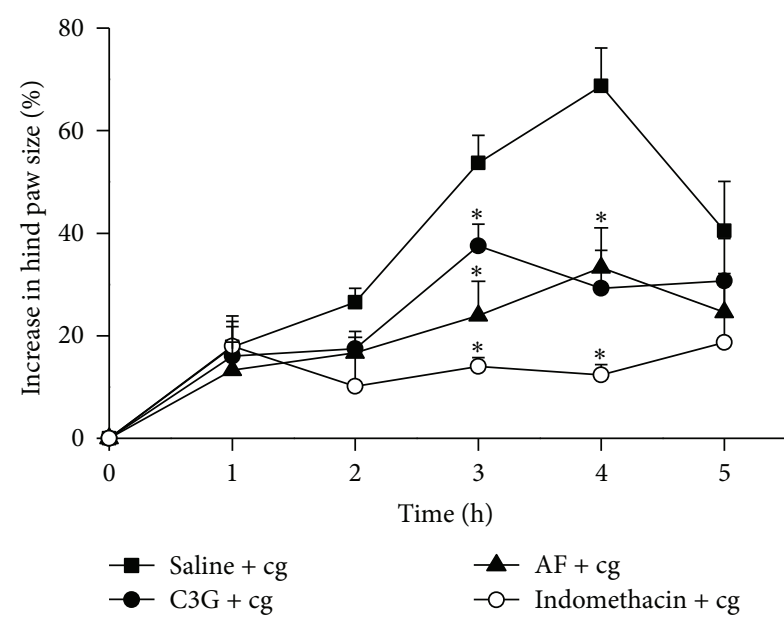

(a)

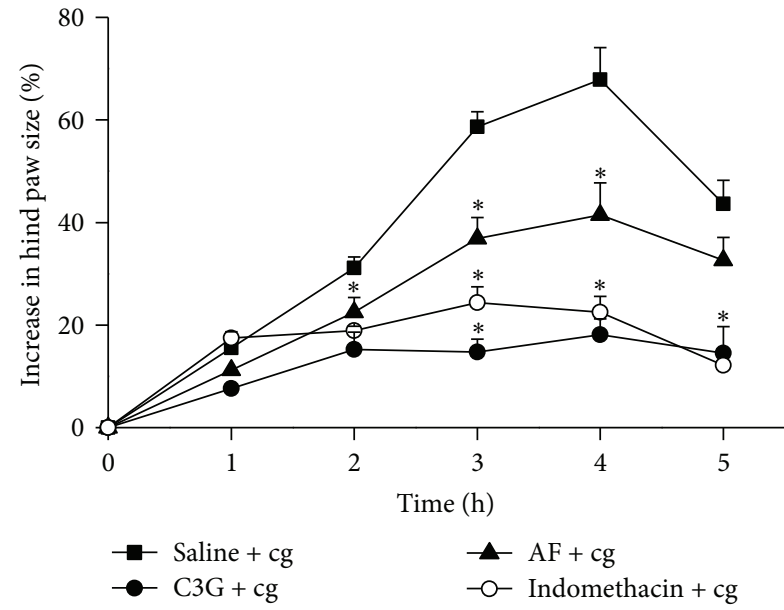

(b)

Figure 2: Effect of C3G and AF on carrageenan-induced paw oedema. Footpad oedema was induced by injection of $\mathrm{cg}(0.5 \% \mathrm{w} / \mathrm{v}$ in saline, i.pl.) and was evaluated by plethysmometry. C3G or AF ( $4 \mathrm{mg} / 100 \mathrm{~g}$ body weight) or indomethacin ( $1 \mathrm{mg} / \mathrm{kg}$, i.v.) or saline (control oedema) was orally administered in two different times: $30 \mathrm{~min}$ before (a) and $1 \mathrm{~h}$ after (b) i.pl. injection of $\mathrm{cg}$. The increase paw size was measured 1 , $2,3,4$, and $5 \mathrm{~h}$ after $\mathrm{cg}$ injection. The time zero corresponds to cg injection. The results were expressed as mean \pm EPM of 8 mice. Statistically significant difference regarding saline (control group) and C3G and AF and Indomethacin groups is expressed as ${ }^{*} P<0.05$.

C3G and AF, either $30 \mathrm{~min}$ before and $1 \mathrm{~h}$ after cg i.p. injection, clearly downregulated COX-2 mRNA expression (50\% reduction) and decreased the levels of COX-2 protein expression, when compared with the control group.

Although some studies have documented that anthocyanins inhibit COX-2 expression in human keratinocyte cell line [15] and cultured macrophages [37, 38] and in asthma model [16], our study provides the first evidence that an anthocyanin mixture or C3G can inhibit, both preventively and therapeutically, the expression of COX-2 protein with a single oral dose. Several lines of evidence clearly established, in in vitro models, that the inhibition of some inflammatory cytokines $[12,16]$ and inhibition of activation of nuclear factor pathway, such as NF- $\kappa \mathrm{B}[10,15]$, could explain the mechanisms of action of anthocyanins on the inhibition of COX-2 expression.

Also, some sources of anthocyanins, such as black soybean anthocyanin and anthocyanins from sweet purple have showed inhibition the COX-2 expression through NF- $\kappa$ B inhibition when administered before the stimulus in inflammation models $[11,12]$.

3.4. Effect of C3G and AF on Carrageenan-Released $P G E_{2}$ in Peritonitis. Further, this study investigated the effect of C3G and AF ( $4 \mathrm{mg} / 100 \mathrm{~g}$ body weight) on $\mathrm{PGE}_{2}$ production, the main inflammatory prostaglandin produced by COX activity, in peritoneal exudates from mice induced by $\mathrm{cg}$. Figures 5(a) and 5(b) showed that i.p. administration of cg induced more than a 25 -fold $(14.5 \pm 2.5 \mathrm{ng} / \mathrm{mL})$ increase in $\mathrm{PGE}_{2}$ generation compared with the groups without the cg stimulus $(0.50 \pm 0.05 \mathrm{ng} / \mathrm{mL})$. The $\mathrm{PGE}_{2}$ concentration was significantly decreased by the oral pretreatment with $\mathrm{C} 3 \mathrm{G}, \mathrm{AF}$, and indomethacin, $30 \mathrm{~min}$ before $\mathrm{cg}$ injection $(4.5 \pm 1.0 \mathrm{ng} / \mathrm{mL}, 5.0 \pm 2.0 \mathrm{ng} / \mathrm{mL}$ and $2.1 \pm 0.1 \mathrm{ng} / \mathrm{mL}$, resp.). In this administration time, the $\mathrm{AF}$ and $\mathrm{C} 3 \mathrm{G}$ promoted approximately $70 \%$ reduction in $\mathrm{PGE} 2$ production by $\mathrm{cg}$ (Figure 5(a)). On the other hand, the oral treatment of AF or C3G, $1 \mathrm{~h}$ after i.p. injection of $\mathrm{cg}$, did not induce any modification in the high levels of $\mathrm{PGE}_{2}$ release by $\mathrm{cg}$ (Figure 5(b)). However, in such experimental condition, the indomethacin suppressed the $\mathrm{PGE}_{2}$ production by $\mathrm{cg}$ stimulus.

Prostaglandin $\mathrm{E}_{2}$ is a product generated by cyclooxygenases from arachidonic acid, and it is an important mediator in the inflammatory process. In this study, it was observed that after $3 \mathrm{~h}$ of administration, cg produced an increase in $\mathrm{PGE}_{2}$ levels into peritoneal cavity. In parallel, the results showed that $\mathrm{C} 3 \mathrm{G}$ produced significant inhibition of $\mathrm{PGE}_{2}$ production when injected $30 \mathrm{~min}$ before cg. However, C3G did not produce such equivalent effectiveness towards $\mathrm{cg}$ induced $\mathrm{PGE}_{2}$ release when administered $1 \mathrm{~h}$ after cg injection. These results are curious because in both administration times used in the present study it was possible to observe that the oral intake of $\mathrm{C} 3 \mathrm{G}$ was effective in inhibiting COX-2 expression. Therefore, this suggests that although COX-2 mRNA and protein expression were detected at $3 \mathrm{~h}$ after cg injection, this isoform of COX did not present catalytic activity in this period of time. In fact, studies have demonstrated that cg-induced $\mathrm{PGE}_{2}$ are produced by COX1 in the first phase, while COX-2-derived $\mathrm{PGE}_{2}$ turned to be involved in the second phase induced by cg injection [35]. In parallel, our data demonstrated that indomethacin was effective to inhibit $\mathrm{PGE}_{2}$ production in both administration 


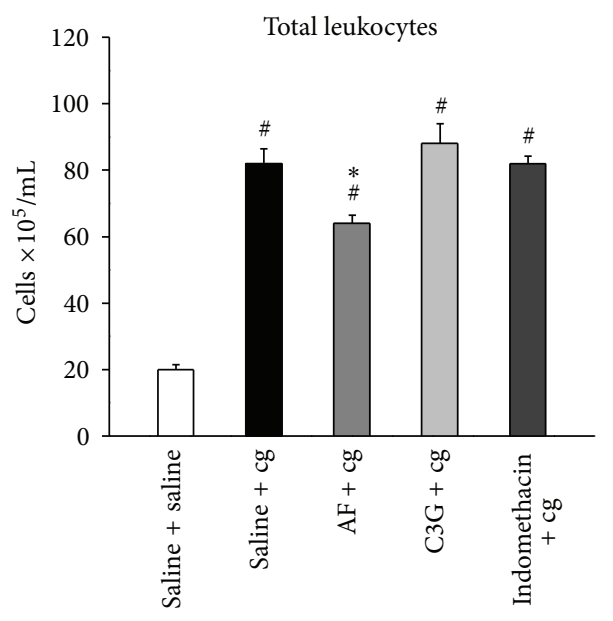

(a)

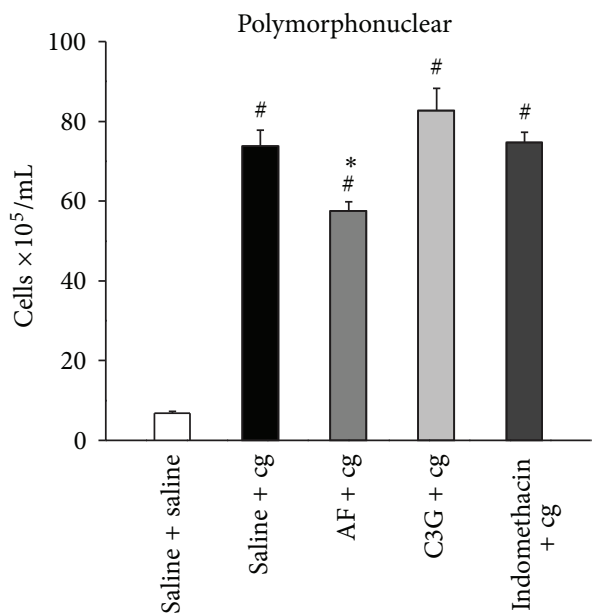

(b)

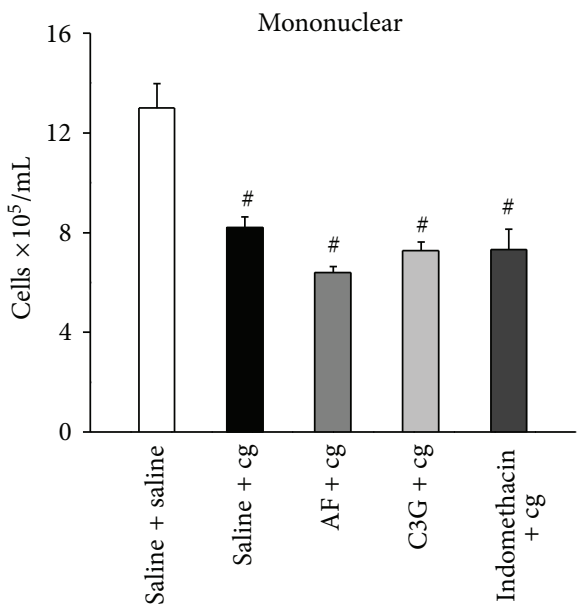

(c)

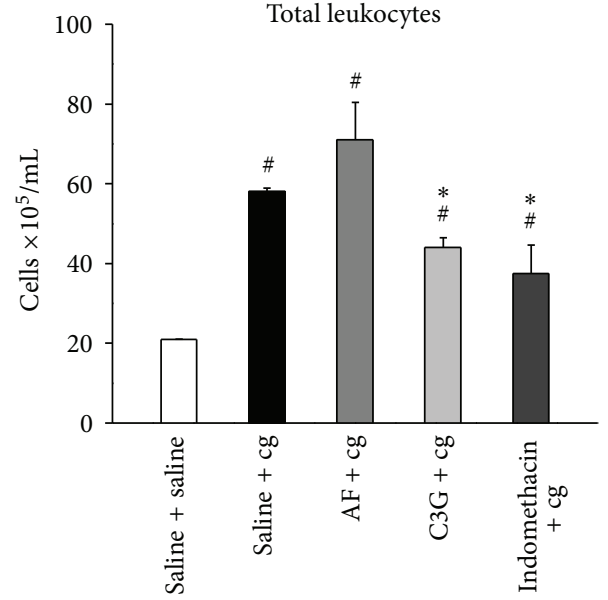

(d)

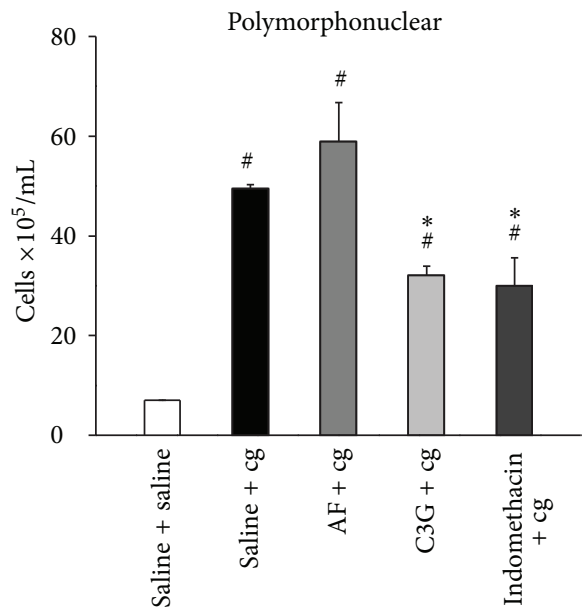

(e)

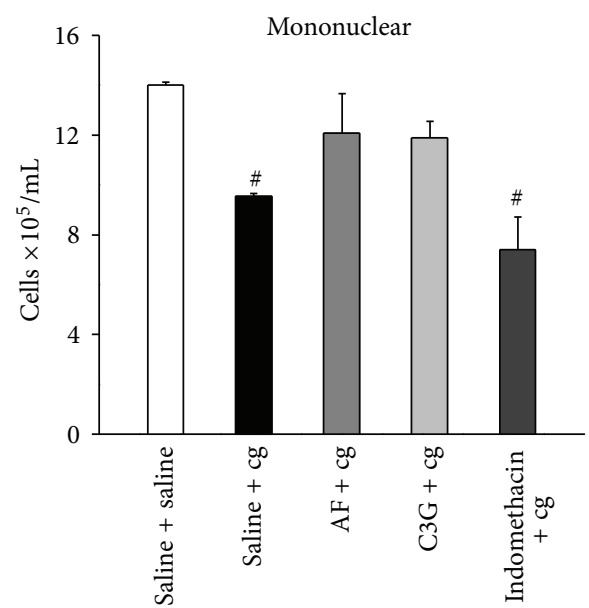

(f)

FIGURE 3: Effect of $\mathrm{C} 3 \mathrm{G}$ and AF on carrageenan-induced leukocyte influx into peritoneal cavity. Groups of mice received C3G or AF $(4 \mathrm{mg} / 100 \mathrm{~g}$ body weight) or indomethacin $(4 \mathrm{mg} / 100 \mathrm{~g}$ body weight) or saline (control) by gavage in two different times: $30 \mathrm{~min}$ before $(\mathrm{a}, \mathrm{b}$, and $\mathrm{c}$ ) and $1 \mathrm{~h}$ after (d, e, and f) cg or saline injection into the peritoneal cavity. Total leukocyte (a, d), PMN (b, e) and MN (c, f) cell counts were determined in peritoneal washes collected $3 \mathrm{~h}$ after cg or saline i.p. injection, as described in Section 2. Values are mean \pm EPM of 8 animals. ${ }^{\#} P<0.05$ when compared with the corresponding group without cg stimulus (saline + saline). ${ }^{*} P<0.05$ when compared with the corresponding control group (saline $+\mathrm{cg}$ ). 


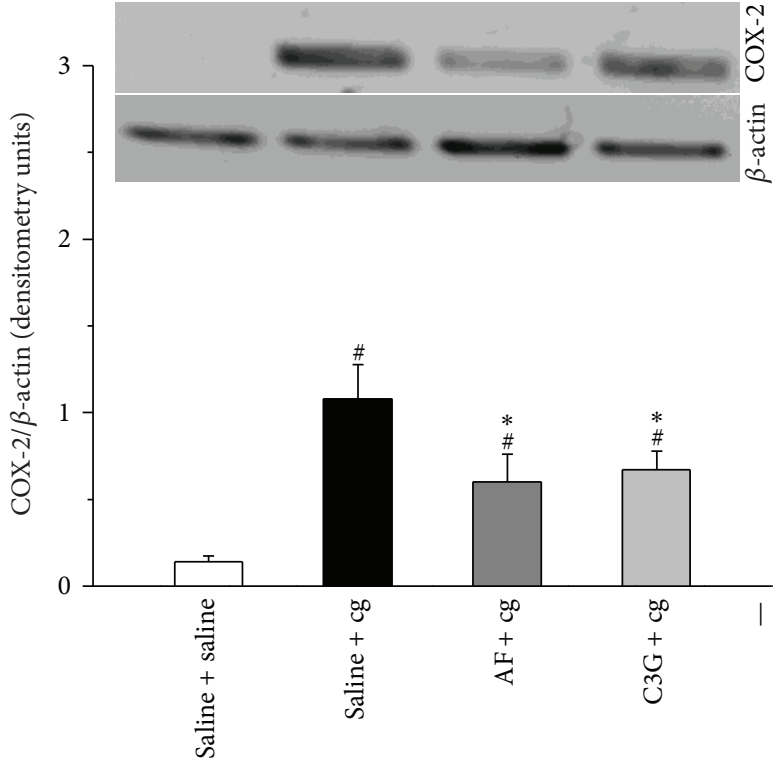

(a)

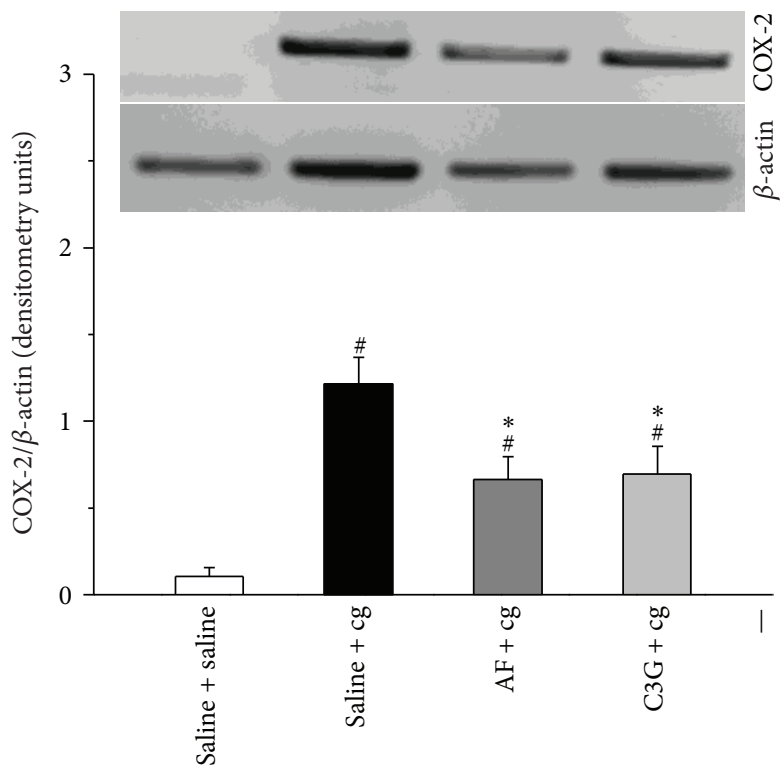

(c)

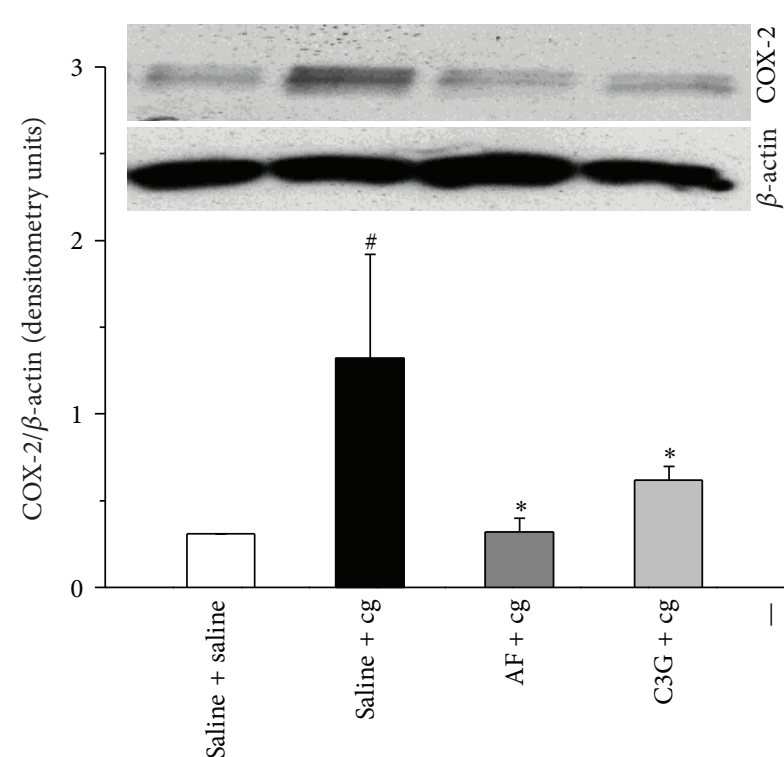

(b)

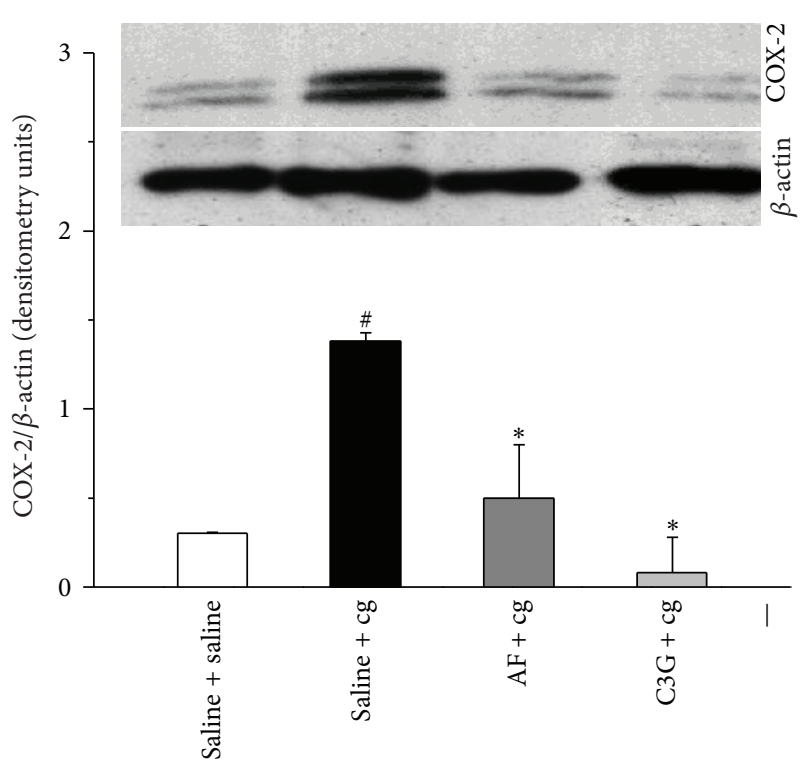

(d)

FIGURE 4: Effect of C3G and AF on carrageenan-induced cyclooxygenase-2 expression in peritoneal leukocytes. Groups of mice received C3G or $\mathrm{AF}$ ( $4 \mathrm{mg} / 100 \mathrm{~g}$ body weight) or saline by gavage in two different times: $30 \mathrm{~min}$ before or $1 \mathrm{~h}$ after $\mathrm{cg}(0.3 \% \mathrm{w} / \mathrm{v})$ or saline injection into the peritoneal cavity. Peritoneal leukocytes were collected $3 \mathrm{~h}$ after i.p. administration of either cg or saline and whole cells were analyzed for COX-2 expression by RT-PCR and western blotting performed, as described in Section 2. (a and c) RT-PCR of COX-2, and $\beta$-actin (loading control); Bar graph shows densitometric analysis of mRNA COX-2. (b and d) Western blotting of COX-2, and $\beta$-actin (loading control) of leukocytes present in the inflammatory exudates; bar graph shows densitometric analysis of protein COX-2. The densities (in densitometry units) were normalized with those of $\beta$-actin. Results were expressed as mean \pm EPM from 8 mice. ${ }^{\#} P<0.05$ when compared with the corresponding group without cg stimulus (saline + saline). ${ }^{*} P<0.05$ when compared with the corresponding control group (saline $+\mathrm{cg}$ ).

times. Although it is generally accepted that nonsteroidal anti-inflammatory drugs such as aspirin and indomethacin are inhibitors of activity of both isoforms of COXs, it is known that these compounds inhibit COX-1 activity more potently than COX-2 in broken cells and in intact cells of mice $[39,40]$. In addition, the absence of $\mathrm{PGE}_{2}$ inhibition when $\mathrm{C} 3 \mathrm{G}$ was administered $1 \mathrm{~h}$ after cg stimulus compared to the preventive effect obtained by $\mathrm{C} 3 \mathrm{G}$ when administered $30 \mathrm{~min}$ before the 


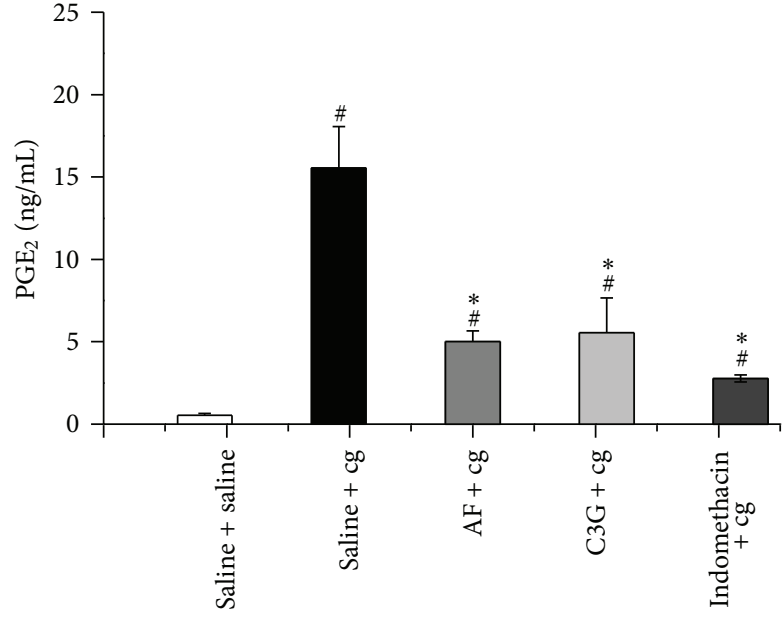

(a)

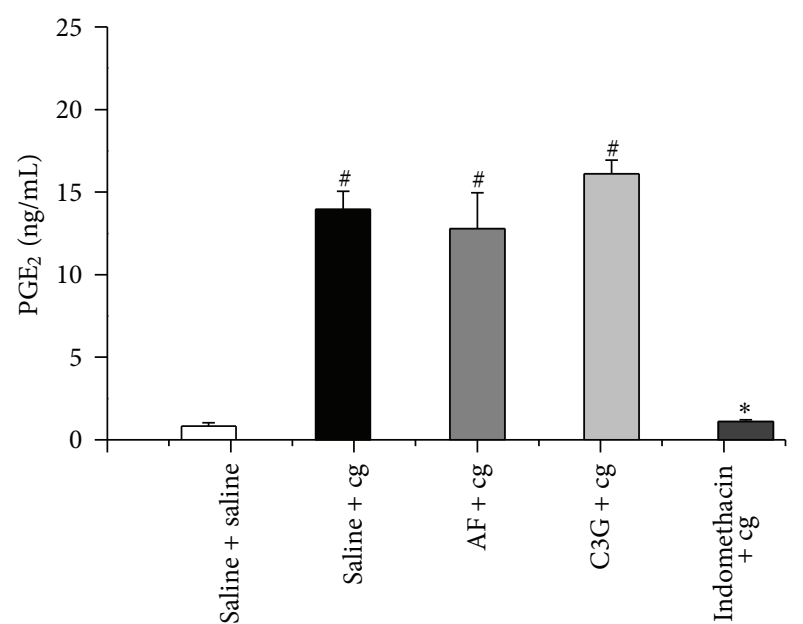

(b)

FIGURE 5: Effect of C3G and AF on carrageenan-released $\mathrm{PGE}_{2}$ in peritonitis. Groups of mice received C3G or AF (4 mg/100 g body weight) or indomethacin $(4 \mathrm{mg} / 100 \mathrm{~g}$ body weight) or saline (control) by gavage in two different times: 30 min before (a) or $1 \mathrm{~h}$ after (b) cg or saline (control) injection into the peritoneal cavity. $\mathrm{PGE}_{2}$ was quantified in peritoneal exudates collected after $3 \mathrm{~h}$ of cg or saline administration. Values are mean \pm EPM of 8 mice. ${ }^{\#} P<0.05$ when compared with the corresponding group without cg stimulus (saline + saline). ${ }^{*} P<0.05$ when compared with the corresponding control group (saline $+\mathrm{cg}$ ).

stimulus may be a reflection of the plasma concentrations of this anthocyanin in each administration time.

\section{Conclusions}

In the present study, $\mathrm{AF}$ and $\mathrm{C} 3 \mathrm{G}$ have been found to be prophylactic or therapeutically efficient on suppressing cg-induced acute inflammation in mice, like oedema and peritonitis, demonstrating to be an anti-inflammatory component from Morus nigra. The results suggest that the antiinflammatory properties of $\mathrm{AF}$ and its major component, the C3G, might be correlated to inhibition of the PMN influx, to downregulation of COX-2 expression, and to inhibition of $\mathrm{PGE}_{2}$ production.

\section{Acknowledgment}

This study was supported by the Fundação de Amparo à Pesquisa do Estado de São Paulo (FAPESP), and Conselho Nacional de Desenvolvimento Científico e Tecnológico (CNPq).

\section{References}

[1] A. Castaneda-Ovando, M. D. Pacheco-Hernandez, M. E. PaezHernandez, J. A. Rodríguez, and C. A. Galán-Vidal, "Chemical studies of anthocyanins: a review," Food Chemistry, vol. 113, no. 4, pp. 859-871, 2009.

[2] M. N. Clifford, "Anthocyanins- nature, occurrence and dietary burden," Journal Science Food Agriculture, vol. 80, no. 7, pp. 1063-1072, 2000.

[3] S. Pacifico, B. D’Abrosca, M. Scognamiglio et al., "Metabolic profiling of strawberry grape (Vitis $\times$ labruscana cv. "Isabella" components by nuclear magnetic resonance (NMR) and evaluation of their antioxidant and antiproliferative properties," Journal of Agricultural and Food Chemistry, vol. 59, no. 14, pp. 7679-7687, 2011.

[4] N. P. Seeram, L. S. Adams, Y. Zhang et al., "Blackberry, black raspberry, blueberry, cranberry, red raspberry, and strawberry extracts inhibit growth and stimulate apoptosis of human cancer cells in vitro," Journal of Agricultural and Food Chemistry, vol. 54, no. 25, pp. 9329-9339, 2006.

[5] P. N. Chen, S. C. Chu, H. L. Chiou, W. H. Kuo, C. L. Chiang, and Y. S. Hsieh, "Mulberry anthocyanins, cyanidin 3-rutinoside and cyanidin 3-glucoside, exhibited an inhibitory effect on the migration and invasion of a human lung cancer cell line," Cancer Letters, vol. 235, no. 2, pp. 248-259, 2006.

[6] T. Matsui, I. A. Ogunwande, K. J. M. Abesundara, and K. Matsumoto, "Anti-hyperglycemic potential of natural products," Mini-Reviews in Medicinal Chemistry, vol. 6, no. 3, pp. 349-356, 2006.

[7] T. Tsuda, F. Horio, K. Uchida, H. Aoki, and T. Osawa, "Dietary cyanidin 3-O- $\beta$-D-glucoside-rich purple corn color prevents obesity and ameliorates hyperglycemia in mice," Journal of Nutrition, vol. 133, no. 7, pp. 2125-2130, 2003.

[8] T. Tsuda, Y. Ueno, T. Yoshikawa, H. Kojo, and T. Osawa, "Microarray profiling of gene expression in human adipocytes in response to anthocyanins," Biochemical Pharmacology, vol. 71, no. 8, pp. 1184-1197, 2006.

[9] K. Wang, P. Jin, S. Cao, H. Shang, Z. Yang, and Y. Zheng, "Methyl jasmonate reduces decay and enhances antioxidant capacity in chinese bayberries," Journal of Agricultural and Food Chemistry, vol. 57, no. 13, pp. 5809-5815, 2009.

[10] C. Pergola, A. Rossi, P. Dugo, S. Cuzzocrea, and L. Sautebin, "Inhibition of nitric oxide biosynthesis by anthocyanin fraction of blackberry extract," Nitric Oxide, vol. 15, no. 1, pp. 30-39, 2006.

[11] Y. P. Hwang, J. H. Choi, H. J. Yun et al., "Anthocyanins from purple sweet potato attenuate dimethylnitrosamine-induced 
liver injury in rats by inducing Nrf2-mediated antioxidant enzymes and reducing COX-2 and iNOS expression," Food and Chemical Toxicology, vol. 49, no. 1, pp. 93-99, 2011.

[12] S. L. Yeh, H. M. Wang, P. Y. Chen, and T. C. Wu, "Interactions of $\beta$-carotene and flavonoids on the secretion of pro-inflammatory mediators in an in vitro system," Chemico-Biological Interactions, vol. 179, no. 2-3, pp. 386-393, 2009.

[13] J. M. Tall, N. P. Seeram, C. Zhao, M. G. Nair, R. A. Meyer, and S. N. Raja, "Tart cherry anthocyanins suppress inflammationinduced pain behavior in rat," Behavioural Brain Research, vol. 153, no. 1, pp. 181-188, 2004.

[14] S. W. Min, S. N. Ryu, and D. H. Kim, "Anti-inflammatory effects of black rice, cyanidin-3-O- $\beta$-d-glycoside, and its metabolites, cyanidin and protocatechuic acid," International Immunopharmacology, vol. 10, no. 8, pp. 959-966, 2010.

[15] K. Tsoyi, H. B. Park, Y. M. Kim et al., "Anthocyanins from black soybean seed coats inhibit UVB-induced inflammatory cylooxygenase-2 gene expression and PGE2 production through regulation of the nuclear factor- $\kappa \mathrm{B}$ and phosphatidylinositol 3-kinase/Akt pathway," Journal of Agricultural and Food Chemistry, vol. 56, no. 19, pp. 8969-8974, 2008.

[16] S. J. Park, W. H. Shin, J. W. Seo, and E. J. Kim, "Anthocyanins inhibit airway inflammation and hyperresponsiveness in a murine asthma model," Food and Chemical Toxicology, vol. 45, no. 8, pp. 1459-1467, 2007.

[17] A. Rossi, I. Serraino, P. Dugo et al., "Protective effects of anthocyanins from blackberry in a rat model of acute lung inflammation," Free Radical Research, vol. 37, no. 8, pp. 891-900, 2003.

[18] N. P. Seeram, R. A. Momin, M. G. Nair, and L. D. Bourquin, "Cyclooxygenase inhibitory and antioxidant cyanidin glycosides in cherries and berries," Phytomedicine, vol. 8, no. 5, pp. 362-369, 2001.

[19] N. M. A. Hassimotto, M. I. Genovese, and F. M. Lajolo, "Identification and characterisation of anthocyanins from wild mulberry (Morus nigra L.) growing in Brazil," Food Science and Technology International, vol. 13, no. 1, pp. 17-25, 2007.

[20] N. M. A. Hassimotto, M. I. Genovese, and F. M. Lajolo, "Absorption and metabolism of cyanidin-3-glucoside and cyanidin-3-rutinoside extracted from wild mulberry (Morus nigra L.) in rats," Nutrition Research, vol. 28, no. 3, pp. 198-207, 2008.

[21] R. Medzhitov, "Origin and physiological roles of inflammation," Nature, vol. 454, no. 7203, pp. 428-435, 2008.

[22] F. A. Fitzpatrick, "Cyclooxygenase enzymes: regulation and function," Current Pharmacology Design, vol. 10, no. 6, pp. 577-588, 2004.

[23] T. D. Warner and J. A. Mitchell, "Cyclooxygenases: new forms, new inhibitors, and lessons from the clinic," FASEB Journal, vol. 18, no. 7, pp. 790-804, 2004.

[24] W. L. Smith, D. L. DeWitt, and R. M. Garavito, "Cyclooxygenases: structural, cellular, and molecular biology," Annual Review of Biochemistry, vol. 69, pp. 145-182, 2000.

[25] H. R. Herschman, J. J. Talley, and R. DuBois, "Cyclooxygenase 2 (COX-2) as a target for therapy and noninvasive imaging," Molecular Imaging and Biology, vol. 5, no. 5, pp. 286-303, 2003.

[26] J. P. Portanova, Y. Zhang, G. D. Anderson et al., "Selective neutralization of prostaglandin E2 blocks inflammation, hyperalgesia, and interleukin 6 production in vivo," Journal of Experimental Medicine, vol. 184, no. 3, pp. 883-891, 1996.
[27] T. G. Brock and M. Peters-Golden, "Activation and regulation of cellular eicosanoid biosynthesis," TheScientificWorldJournal, vol. 7, pp. 1273-1284, 2007.

[28] N. V. Chandrasekharan, H. Dai, K. L. T. Roos et al., "COX3 , a cyclooxygenase-1 variant inhibited by acetaminophen and other analgesic/antipyretic drugs: cloning, structure, and expression," Proceedings of the National Academy of Sciences of the United States of America, vol. 99, no. 21, pp. 13926-13931, 2002.

[29] B. Kis, J. A. Snipes, T. Isse, K. Nagy, and D. W. Busija, "Putative cyclooxygenase-3 expression in rat brain cells," Journal of Cerebral Blood Flow and Metabolism, vol. 23, no. 11, pp. 1287-1292, 2003.

[30] U. K. Laemmli, "Cleavage of structural proteins during the assembly of the head of bacteriophage T4," Nature, vol. 227, no. 5259, pp. 680-685, 1970.

[31] J. S. Kang, Y. J. Jeon, S. K. Park, K. H. Yang, and H. M. Kim, "Protection against lipopolysaccharide-induced sepsis and inhibition of interleukin- $1 \beta$ and prostaglandin E2 synthesis by silymarin," Biochemical Pharmacology, vol. 67, no. 1, pp. 175-181, 2004.

[32] Y. Bezugla, A. Kolada, S. Kamionka, B. Bernard, R. Scheibe, and P. Dieter, "COX-1 and COX-2 contribute differentially to the LPS-induced release of PGE2 and TxA2 in liver macrophages," Prostaglandins and Other Lipid Mediators, vol. 79, no. 1-2, pp. 93-100, 2006.

[33] P. Pradelles, J. Grassi, and J. Maclouf, “Enzyme immunoassays of eicosanoids using acetylcholine esterase as label: an alternative to radioimmunoassay," Analytical Chemistry, vol. 57, no. 7, pp. 1170-1173, 1985.

[34] O. M. E. Abdel-Salam, A. R. Baiuomy, S. El-batran, and M. S. Arbid, "Evaluation of the anti-inflammatory, anti-nociceptive and gastric effects of Ginkgo biloba in the rat," Pharmacological Research, vol. 49, no. 2, pp. 133-142, 2004.

[35] I. Posadas, M. Bucci, F. Roviezzo et al., "Carrageenan-induced mouse paw oedema is biphasic, age-weight dependent and displays differential nitric oxide cyclooxygenase-2 expression," British Journal of Pharmacology, vol. 142, no. 2, pp. 331-338, 2004.

[36] H. L. Malech and J. I. Gallin, "Current concepts: immunology-neutrophils in human diseases," The New England Journal of Medicine, vol. 317, no. 11, pp. 687-694, 1987.

[37] X. H. Jin, K. Ohgami, K. Shiratori et al., "Effects of blue honeysuckle (Lonicera caerulea L.) extract on lipopolysaccharideinduced inflammation in vitro and in vivo," Experimental Eye Research, vol. 82, no. 5, pp. 860-867, 2006.

[38] K. J. Woo, Y. J. Jeong, H. Inoue, J. W. Park, and T. K. Kwon, "Chrysin suppresses lipopolysaccharide-induced cyclooxygenase-2 expression through the inhibition of nuclear factor for IL-6 (NF-IL6) DNA-binding activity," FEBS Letters, vol. 579, no. 3, pp. 705-711, 2005.

[39] J. C. Frölich, "A classification of NSAIDs according to the relative inhibition of cyclooxygenase isoenzymes," Trends in Pharmacological Sciences, vol. 18, no. 1, pp. 30-34, 1997.

[40] J. A. Mitchell, P. Akarasereenont, C. Thiemermann, R. J. Flower, and J. R. Vane, "Selectivity of nonsteroidal antiinflammatory drugs as inhibitors of constitutive and inducible cyclooxygenase," Proceedings of the National Academy of Sciences of the United States of America, vol. 90, no. 24, pp. 11693-11697, 1993. 

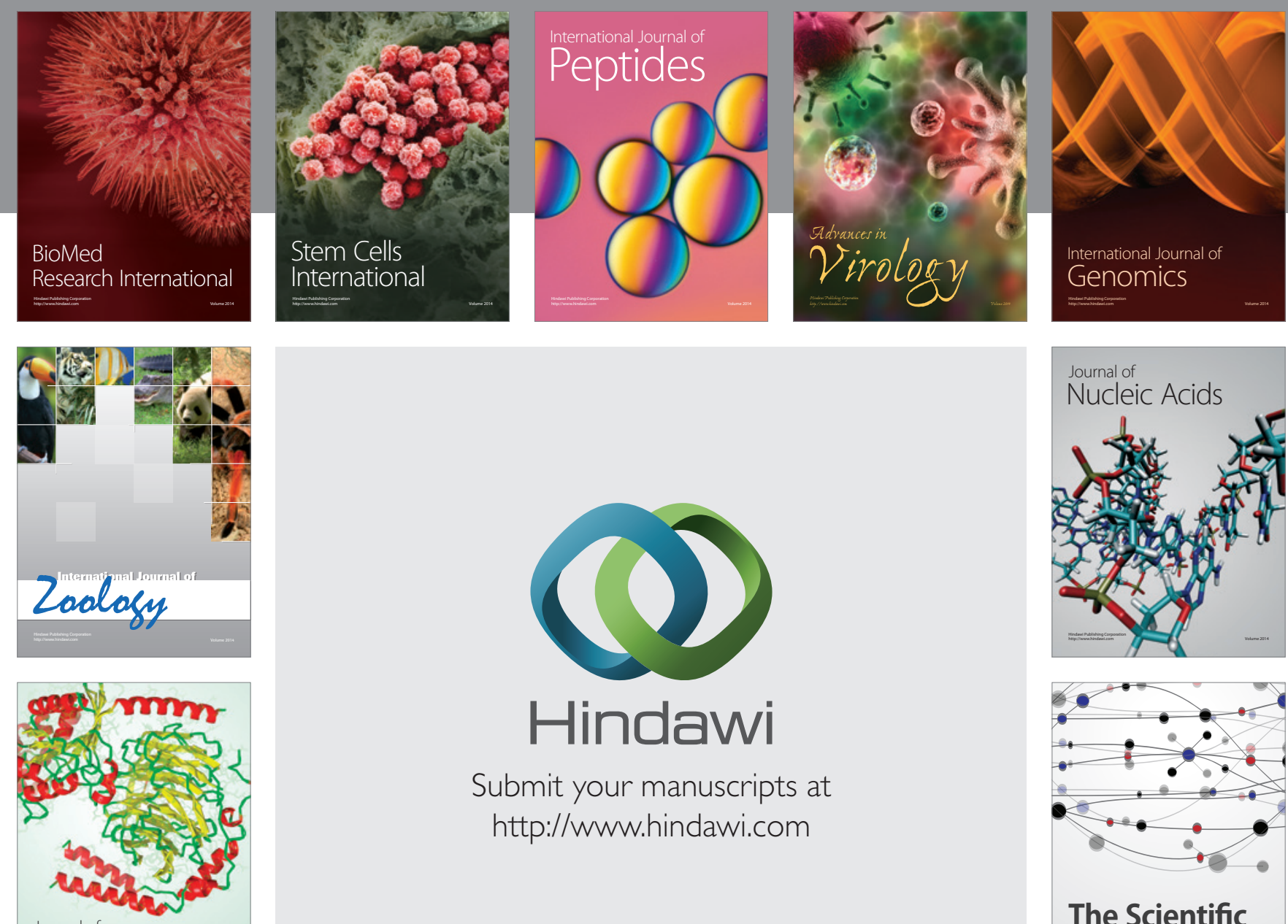

Submit your manuscripts at

http://www.hindawi.com

Journal of
Signal Transduction
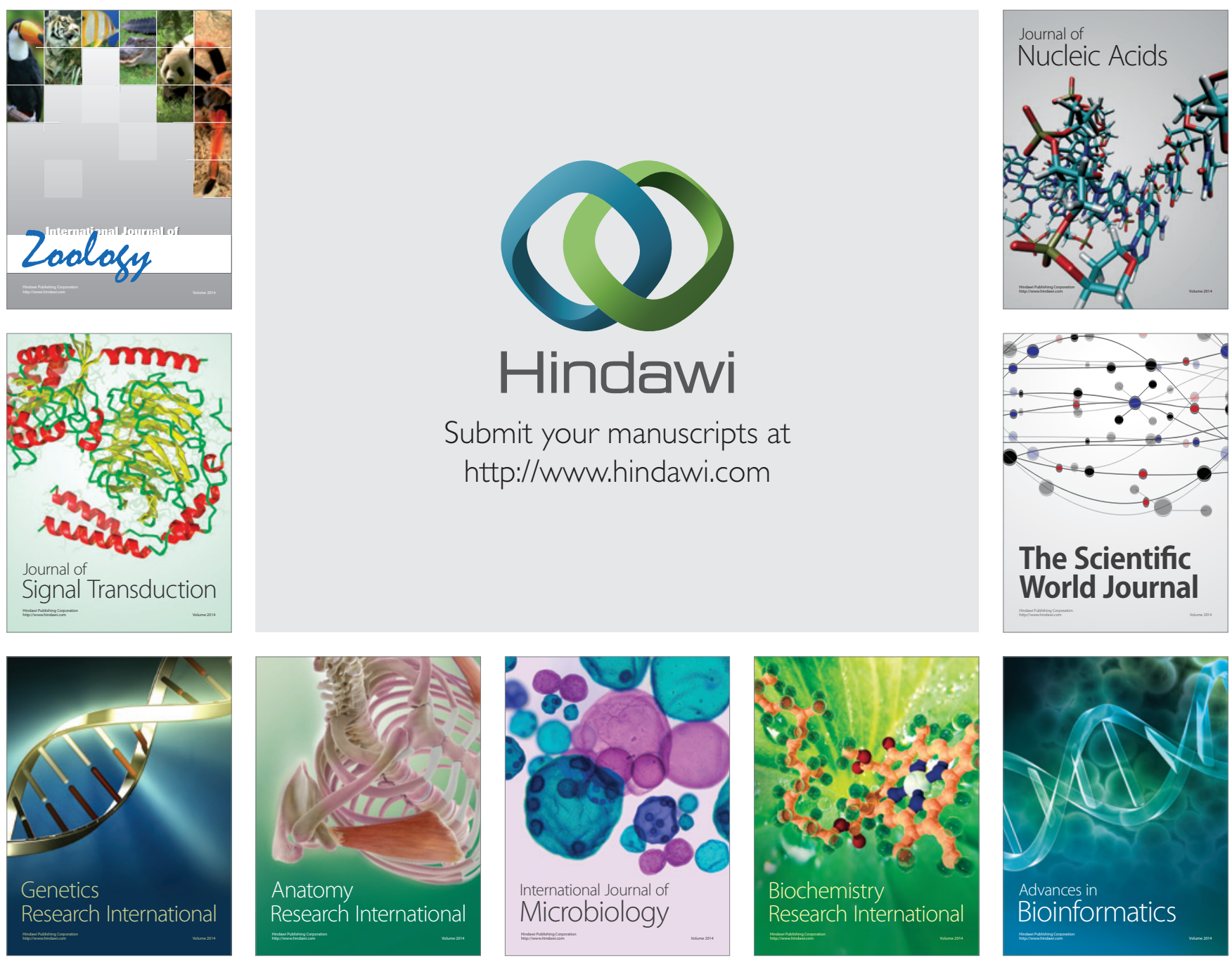

The Scientific World Journal
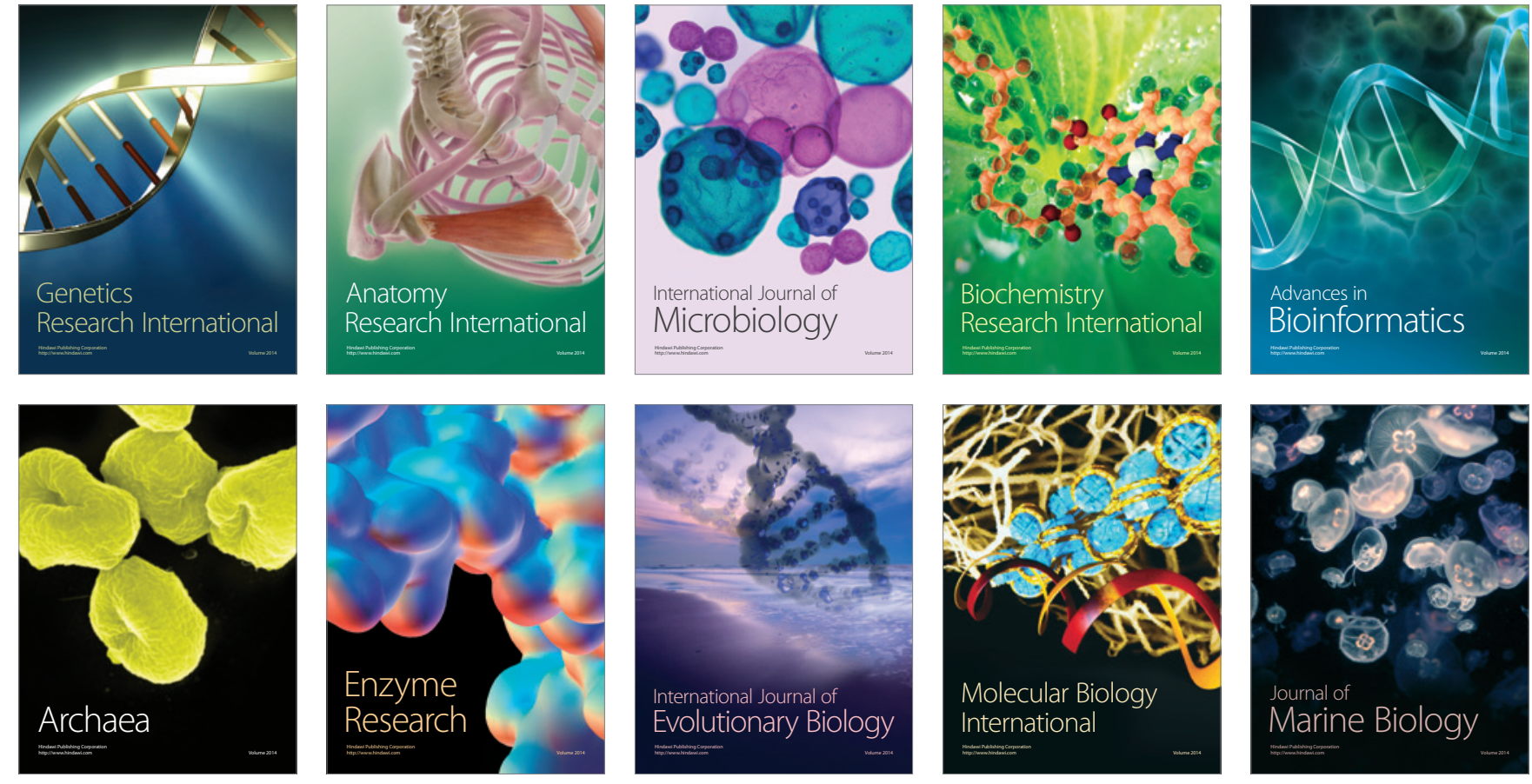